\title{
The Determinants of Food Price Inflation in Pakistan: An Econometric Analysis
}

\author{
Faheem Ur Rehman ${ }^{1}$, Dilawar Khan ${ }^{2, *}$ \\ ${ }^{1}$ Department of Economics, Abasyn University Peshawar, Pakistan \\ ${ }^{2}$ Department of Economics, Kohat University of Science \& Technology, Pakistan
}

Copyright $(\mathcal{C} 2015$ by authors, all rights reserved. Authors agree that this article remains permanently open access under the terms of the Creative Commons Attribution License 4.0 International License

\begin{abstract}
This study seeks to identify the factors affecting food price inflation in Pakistan during 1990-2013. The study applied various econometric tests i.e. Augmented Dickey Fuller, Vector Error Correction model and Johansen co-integration test. The econometric results show that indirect taxes and food exports have positive and significant impact on food price inflation while government subsidy and GDP are negatively correlated with food price inflation in Pakistan. The Johansen co-integration test also shows long-run relation of indirect taxes, food export and subsidy with food price inflation. It is recommended that government should give attention to the agricultural sector and also reduce the taxes on food items.
\end{abstract}

Keywords Taxes, GDP, Subsidy, Inflation, Pakistan

\section{Introduction}

Food price inflation is worldwide issue. It is not only the problem of less developed countries, at also affected the developed countries of the world economy. Especially, it is affected by poor people of the economy because lower income people spend $75 \%$ of their income on food items, $\mathrm{UN}$ [1]. Controlling food price inflation is make one of the big task for policy makers. This job is complex as they require thinking a number of Structural, demand, and external, determinants that are involved in planning food prices including, GDP growth rate, taxes, subsidies, the quantity of food, Food exports and imports, in that particular year as well as in the previous years.

The global market prices of foremost food commodities such as vegetable oil, Sugar and food grain etc. which are major important items used in every family have risen sharply by more than $60 \%$ in just two years approximately in the worldwide, Trostle[2].

In 1972 - 2008 the average food price inflation was recorded $9.9 \%$ in Pakistan. From the year $2003-2004$ and $2004-2005$ the food inflation rate rise up to 12.5 percent.
From the year 2007 - 2008 the food inflation rate was 17 percent. The cruelty of the problem arose when it jump up to the 26.6 percent in $2008-2009$, which was the maximum inflation in 23 years. A raise in food prices inflation in Pakistan is generally connected with the decrease in wheat production, increase in global food prices, political factors in economy and mismanagement etc. Anam \& et al. [3].

There are numerous factors which affect directly or indirectly food inflation, some of the determinants are: Gross Domestic Product (GDP) when the growth rate of GDP increases the inflation rate decreases. Thus the relationship between GDP and food inflation is negative, Adnan and Ali[4]. Many past studies recommended that the relationship between GDP and food inflation is positive but most of the study find out that the impact of GDP on inflation is negative. According to Ahsan \& et al. [5] the influence of government subsidy on food inflation is negative. When government subsidizes any sector of the economy the prices of that sector decreases. For example, when government gives subsidy on wheat the price of wheat will be decreases. Furthermore, when indirect taxes increases the food price inflation also rises, Changchun and Sean[6]. Because when commodity taxes increase it include in the cost of a products which increases the price of the items. Moreover, an export of food items increases it raise the prices of food commodities, Abdullah and Kaleem[7]. Especially, when poor countries of the world export any commodity the supply will diminish of that item in his own domestic market, the demand will decreases, in response the prices will boosts up.

\section{Literature Review}

Balkrishnan[8] employs srtuctralist approach through error correction specification for modeling inflation in India. He observed that an increase in raw material costs and wages were the key factors of increasing prices in industrial sector. In agricultural prices of food grains prices were determined by per capita availability, per capita income and government procurement of food grain. Balkishnan[9] observed that 
structuralist model was superior to that of the monetarist model.

Khan and Qasim[10]demonstrated that food inflation in Pakistan is driven by value added in manufacturing, the wheat support prices and the prices of utilities. Non-food inflation is determined by import, energy prices and supply of money. It is quite clear that changes in the wheat support prices affect the prices of food index, given that wheat product account for $14 \%$ of the index., Tan \& et al.[11] conducted a research in Malaysian economy to determine the impact of important internal and external economic factors on Malaysian inflation and also to examine the to inspect the presence of international and intra-ASEAN inflation diffusion to Malaysian inflation; they have used quarterly basis time series data of eleven internal and external economic variables (internal consumer price index, exchange rate, capital inflow, money supply, Gross domestic product/income, interest rate, private consumption, trade balance, government expenditure, world inflation and rest of ASEAN's inflation) from the period 1973:1 to 1997:2 and applied multivariate co-integration to error correction model along with impulse response functions and variance decomposition techniques. Result shows that external economic variables have significant impact on Malaysians inflation.

Kemal[12] found that in long-run, an increase in growth of money supply results in raise in general inflation including food price inflation in Pakistan. The study employs co-integration technique on quarterly data from $1975-76$ to $2003-4$. The results give support for the quantity theory of money and also suggest that money supply perform in short-run period in less than a year. In addition Qayyum[13] investigates a strong correlation between growth of money and inflation. Excess money supply growth has been the serious contributor to the increasing in general inflation including food price inflation in Pakistan in the reciprocal period.

Schimimelpfenning and Khan[14] investigated that monetary factors determine the prices rise in Pakistan. An increase in growth rate of Private sector and money supply directly affect inflation. They consider credit to private sectors and money supply as a standard monetary variables wheat support prices and exchange rate as supply side factors. The Asian Development Bank [15] found three sets of determinants which are the major causes of high food inflation in under developed countries of Asia including Pakistan. First is the distinction between demand and supply. Second is the differentiation between cyclical and structural factors and the third is the relationship between domestic and international markets.

Abdullah and Kaleem[16] originated an important factor of food price inflation in Pakistan. Johansen co integration analysis technique has been applied on time series data for the period $1972-2008$ to find out long-run results. The study demonstrates that per capita GDP, money supply, agricultural support prices, import and food export are main factors of increasing food price. Khan et al. [17] described the considerable causes of recent inflation trend in Pakistan using time series data of $1972-2005$. They noted that government sector borrowing, real demand, private sector borrowing, import prices, exchange rate, government taxes, previous year consumer price index and wheat support prices are directly affecting the consumer price index of Pakistan.

Akhtar[18] presented the relationship between prices of food, export and import of chosen food products (Fourteen items) in Pakistan by employing time series data. The trade in rudimentary petroleum commodities has also been considered as the explanatory variable, as these prices influence the food prices indirectly. The study shows that in case of export quantity the affect was more dominant rather than the unit value effect on fish, rice and vegetables of foreign exchange. It bears more risk of food price inflation. To control food inflation in the long run the study emphasizes the rise in production of food items.

Khan and Gills[19] explored the elements of food price inflation in Pakistan for the period 1970 - 2007. For experimental judgment they popularized four models to measure four different symbols of inflation (SPI, WPI, GDP deflator and CPI) and used explanatory variables like, exchange rate, budget deficit, and wheat support prices, value of imports, wheat, sugar, rice, cotton, support prices and supply of money. One of the findings is that wheat support prices has no serious effect on WPI, SPI, or CPI in long run, but significant impact on GDP deflator.

Mushtaq \& et al.[20] applies Johnson co-integration approach to check the role of monetary and macroeconomic variables on wheat prices of Pakistan. Long run relationship exists among the variables. By employing the augmented dickey-fuller test whereas all the variables are stationary at first difference excluding trade openness. They originated that there as significant long run impact of trade openness, real exchange rate, real wheat prices and real money supply. The study justifies that there should be focus on rising the wheat supply through increased production or through trade along with some athletic effort to become stable the Pakistani rupees across other currencies. Nguyen \& et al. [21] found a plain inflation macroeconomic model to empirically examine the CPI inflation determinants for Vietnam over the time span 2001 - 2009. They are mainly concerned in investigate the relationships among rice prices, crude oil prices, inflation and exchange rate. They found that the rice and oil prices, as well as supply of money are the significant factors of CPI by applying time series evaluation method.

Faiza[22] studied to test the impact of gross domestic product (GDP) unemployment, fiscal deficit and interest rate, on inflation rate in Pakistani economy by using the data of 1990 - 2011. The result shows that there is negative relationship between inflation rate and unemployment and fiscal deficit, while positive relationship between GDP, interest rate and inflation rate. Abdullah and Kalim[23] applied the same methodology and determined the factors which were responsible for food inflation in Pakistan and concluded that food price inflation was not a monetary phenomenon in case of Pakistan. In the short run, only 
support prices, food exports and inflation expectations affected food price inflation. Kemal and Ali[24] found the long run relationship among the variables i.e. money supply, GDP, Agricultural sector subsidy and CPI inflation, by using the data during $1970-2010$.

\section{Research Methodology}

This section presents the variables, data sources, theoretical framework and analytical techniques.

\section{Data Sources}

The fundamental aim of the study is to quantify the impact of GDP, Subsidy, indirect Taxes and Food export on Food price inflation. This study uses time series data during $1990-$ 2013 from Pakistan, all data is taken in percentage from WDI (world development indicator) 2014 online database, except agricultural subsidy which is taken from Agricultural statistical year book. Moreover, consumer price index is taken as proxy of Food Price Inflation.

\section{Relationship between GDP and Food Price Inflation}

The relationship between consumer price index and GDP is negative. It means that with the increase of GDP inflation also raises. The same study has been elaborated by Khan and Qasim[25] and Khan[26].

\section{Relationship between Government Subsidy and Food Price Inflation}

The impact of subsidy on inflation is negative. The negative sign shows that as when government increases the subsidy food prices become decline and vice versa. The same perception is given by $\mathrm{UN}$ [27] and Ghaffar \& et al. [28].

\section{Relationship between Food Price Inflation and Indirect Taxes}

According to Qadir \& et al.[29] and Balqees[30] when indirect taxes increase the food prices also increases. It indicates that the relationship between food price and indirect taxes is positive.

\section{Relationship between Food Price Inflation and Indirect Taxes}

When export of food products boost up the food prices also accelerated. There is positive relationship between food export and food prices. The same view has given by Ayalew[31], Abdullah and Kaleem[32] and Josef \& et al.[33].

\section{Unit Root Test}

Unit Root Test will be used to investigate whether the data is stationary or not. A process is said to be stationary if its variance, covariance and its mean remains constant over time.

$$
\gamma_{\mathrm{t}}=\varnothing \gamma_{\mathrm{t}-1}+\epsilon_{\mathrm{t}}
$$

The explanation is as.

Case: $1 . \varnothing<1$ therefore the data is stationary.

Case: $2 . \varnothing>1$ where in this case the series explodes.

Case: $3 . \varnothing=1$ where in this case the series contains the unit root is non-stationary.

The study uses Augmented Dickey Fuller (ADF) test to detect the data for stationary. Furthermore, these test also used for elimination of the Autocorrelation problem. The three form of $\mathrm{ADF}$ is given below.

$$
\begin{gathered}
\Delta \mathrm{Y}_{\mathrm{t}}=\gamma \mathrm{Y}_{\mathrm{t}-1}+\sum_{\mathrm{i}=1}^{\mathrm{p}} \beta_{\mathrm{i}} \Delta \mathrm{Y}_{\mathrm{t}-1}+\mathrm{e}_{\mathrm{t}} \\
\Delta \mathrm{Y}_{\mathrm{t}}=\alpha_{o}+\gamma \mathrm{Y}_{\mathrm{t}-1}+\sum_{\mathrm{i}=1}^{\mathrm{p}} \beta_{\mathrm{i}} \Delta \mathrm{Y}_{\mathrm{t}-1}+\mathrm{e}_{\mathrm{t}} \\
\Delta \mathrm{Y}_{\mathrm{t}}=\alpha_{o}+\alpha_{1} \mathrm{t}+\gamma \mathrm{Y}_{\mathrm{t}-1}+\sum_{\mathrm{i}=1}^{\mathrm{p}} \beta_{\mathrm{i}} \Delta \mathrm{Y}_{\mathrm{t}-1}+\mathrm{e}_{\mathrm{t}}
\end{gathered}
$$

Where $\alpha_{0}$ is intercept term, $\alpha_{1}$ is co-efficient of trend variable, $\mathrm{e}_{\mathrm{t}}$ is error term and $\sum_{i=1}^{p}$ shows the number of lags included in the model. Lag length is determined on the basis of Akaik Information Criterion (ACK) and Schwartz Bayesian Criterion (SBC)

\section{Co-integration Test}

The fundamental concept is that if there are economic time series data that are integrated and of the same order (which means they are non-stationary), which we know are related, then we try to check whether we can find a way to combine them together into a single series which is itself non-stationary. It is possible that the series exhibits this property is called co-integration.

Autocorrelation is correlation between number of series of observations ordered in time (as in time series data) or space (as in cross-sectional data). Durbin - Watson test is used to check the problem of Autocorrelation. Breush - Godfrey Lagrange Test can also be used to detect the problem of Serial Correlation.

\section{Diagnostic Test}

Diagnostic test were conducted to model specification problem, normality in the residuals and serial correlation problem.

\section{Results and Discussion}

The stationarity of the factors is examined by applying ADF test before conducting test for Johansan Co-integration test. The test is uses to find out the order of integration on level as well as on the first difference. Government subsidy and CPI are not stationary at level. Furthermore, all the selected variables are stationary at first difference. The results of $\mathrm{ADF}$ are given below. 


\section{Results of Augmented Dickey Fuller Test (ADF)}

\begin{tabular}{|c|c|c|c|c|}
\hline \multirow[b]{2}{*}{ Variables } & \multicolumn{2}{|c|}{ Level } & \multicolumn{2}{|c|}{$\mathrm{I}^{\text {st }}$ difference } \\
\hline & Level & Intercept and Trend & Level & Intercept and Trend \\
\hline CPI & $\begin{array}{c}-2.241 \\
(0.1980)\end{array}$ & $\begin{array}{l}-2.185 \\
(0.474)\end{array}$ & $\begin{array}{c}5.989 \\
(0.0001)^{*}\end{array}$ & $\begin{array}{c}-5.84 \\
(0.0005)^{*}\end{array}$ \\
\hline GDP & $\begin{array}{c}-3.37 \\
(0.0252) *\end{array}$ & $\begin{array}{c}-3.37 \\
(0.0252)^{*}\end{array}$ & $\begin{array}{c}-5.544 \\
(0.0002)^{*}\end{array}$ & $\begin{array}{c}-5.411 \\
(0.001)^{*}\end{array}$ \\
\hline $\mathrm{S}$ & $\begin{array}{c}-1.49 \\
(0.518)\end{array}$ & $\begin{array}{c}1.595 \\
(0.7634) \\
\end{array}$ & $\begin{array}{c}-5.078 \\
(0.0005)^{*}\end{array}$ & $\begin{array}{c}-5.011 \\
(0.0031)^{*}\end{array}$ \\
\hline $\mathrm{TX}$ & $\begin{array}{l}-1.587 \\
(0.472)\end{array}$ & $\begin{array}{c}3.336 \\
(0.0854)^{*}\end{array}$ & $\begin{array}{c}-5.685 \\
(0.0001)^{*}\end{array}$ & $\begin{array}{c}-5.693 \\
(0.0007)^{*}\end{array}$ \\
\hline$X$ & $\begin{array}{c}0.848 \\
(0.785)\end{array}$ & $\begin{array}{c}-2.562 \\
(0.299)\end{array}$ & $\begin{array}{c}-5.238 \\
(0.0004)^{*}\end{array}$ & $\begin{array}{c}-5.56 \\
(0.0001)^{*}\end{array}$ \\
\hline
\end{tabular}

Note: The value in the braces shows probability value and others are t-statistic

\section{Results of Vector Error Correction Model (VECM)}

\begin{tabular}{|c|c|c|c|c|}
\hline Variables & Co-efficient & Standard Error & t-Statistic & Probability Value \\
\hline $\mathrm{C}$ & -0.511160 & 0.729137 & -0.701048 & 0.4940 \\
\hline $\mathrm{D}(\mathrm{S})$ & -0.162485 & 0.100677 & -1.613929 & 0.1274 \\
\hline $\mathrm{D}(\mathrm{TX})$ & 0.570450 & 0.286133 & 1.993650 & 0.0647 \\
\hline $\mathrm{D}(\mathrm{X})$ & 0.585752 & 0.341625 & 1.714604 & 0.1070 \\
\hline $\mathrm{D}(\mathrm{GDP})$ & -0.696548 & 0.352655 & -1.975155 & 0.0669 \\
\hline $\mathrm{E}_{\mathrm{t}-1}$ & -0.336741 & 0.221974 & -1.517025 & 0.1501 \\
\hline
\end{tabular}

$\mathrm{R} 2=0.45$, F-Statistic $=2.49$, D. Watson value $=1.95$

The D.W is equal to 1.95 it means that there is absence or no problem of Autocorrelation. The $\mathrm{R}^{2}$ is 0.45 which indicates that 45 percent changes in dependent variable are explained by the independent variables. The influence of indirect taxes and inflation is positive. It means that as when indirect taxes. We can see from the above table the impact of subsidy on CPI-inflation is negative and insignificant in short run. The negative sign indicates that as when subsidy increases the inflation rate decreases and vice versa. Increases inflation also rises. Similarly export impact on inflation positively but insignificantly. The positive sign indicates that with the raise of exports of food products CPI also increases. Moreover GDP influence on inflation negatively and significantly. It means that when GDP increases inflation also boost up. Our study justifies the results of Ahmad \& et al. [34], Anam \& et al. [35] and Abdullah and Kalim[36].

\section{Results of Co-integration Test}

\begin{tabular}{|c|c|c|c|c|c|}
\hline Null Hypothesis & Alternative Hypothesis & Trace statistic & $5 \%$ critical value & Max-eigen value & $5 \%$ critical value \\
\hline $\mathrm{R}=0$ & $\mathrm{R}=1$ & 53.71797 & $47.85613(0.12)$ & 25.66926 & $\begin{array}{c}27.58434 \\
(0.08)^{* *}\end{array}$ \\
\hline $\mathrm{R}=1$ & $\mathrm{R}=2$ & 28.04870 & $29.79707(0.07)^{* *}$ & 16.71353 & $21.13162(0.18)$ \\
\hline $\mathrm{R}=2$ & $\mathrm{R}=3$ & 11.33517 & $15.49471(0.19)$ & 8.103786 & $14.26460(0.36)$ \\
\hline $\mathrm{R}=3$ & $\mathrm{R}=4$ & 3.231388 & $3.841466(0.07)^{* *}$ & 3.231388 & $\begin{array}{c}3.841466 \\
(0.07)^{* *}\end{array}$ \\
\hline
\end{tabular}

Note: $*$ denotes significant at $5 \%$ and $* *$ indicates that significant at $10 \%$, where the value in braces shows probability values.

By applying Johansson Co-integration test one can see from the table that two of the selected variables are significant at $10 \%$, it means that there are long-run relationship exists in the factors. So we rejected the null hypothesis against the alternative hypothesis $(\mathrm{r}=0, \mathrm{r}=1, \mathrm{r}=2, \mathrm{r}=3)$ and $(\mathrm{r}=1, \mathrm{r}=2, \mathrm{r}=3, \mathrm{r}=4)$ respectively.

\section{Results of Diagnostic Test}

\begin{tabular}{|c|c|c|}
\hline Breusch-Godfrey Serial Correlation LM Test & Heteroskedasticity Test: ARCH & Jarque-Bera Normality Test \\
\hline 1.585491 & 0.034132 & 0.5548 \\
$(0.5647)$ & $(0.8618)$ & $(0.7577)$ \\
\hline
\end{tabular}

Note: The values in the braces show Probability values.

By using various test i.e. LM test for serial correlation, $\mathrm{ARCH}$ for Heterosckedasticity and Jarque-Bera for normality of the model. One can conclude that there is no problem of Herterskedasticity, Autocorrelation. Furthermore, the functional form of the model is accurate and normally distributed. 


\section{Conclusions and Recommendations}

\section{Conclusions}

The major objective of this paper is to examine the main factors affecting food price inflation in Pakistan. The paper applied different econometric techniques to examine unit root, short and long-run relationship among the variables. The econometric results conclude that indirect taxes and food exports have positive and significant effect on food price inflation. Government subsidy and GDP are negatively related with food price inflation in Pakistan. The Johansen co-integration test also confirms long-run relation of indirect taxes, food export and subsidy with food price inflation.

\section{Recommendations}

i. It is recommended that efforts should be made to enhance the economic growth to decrease the inflation of the economy.

ii. It is suggested that government should encourage the production of agricultural commodities.

iii. It is recommended that government should reduce the taxes on food items.

iv. It is also suggested that government should focus on food imports substitutes in the country.

v. Government should control the strategic planning and management.

\section{REFERENCES}

[1] United Nations., High Food Prices in Pakistan: Impact Assessment and the Way Forward. UN Inter Agency Assessment Mission. Prepared for Ministry of Food, Agriculture and Livestock, Government of Pakistan, Islamabad., 2008.

[2] Trostle, R., Global Agriculture Supply and Demand: Factors Contributing to the Recent Increase in Food Commodity Prices. A Report from the Economic Research Service. http://www.ers.usda.gov/Publications/WRS0801/ WRS0801.pdf., 2008.

[3] Anam, S., Allah R., And Zeeshan F., Determinants of Food Price Inflation in Pakistan. European Academic Research, Vol. I, , ISSN, 2286-4822 www.euacademic.org. 2014.

[4] Adnan And Ali., Determinants of Food Price Inflation in Pakistan. European Academic Research, Vol. I. ISSN 1995-9344,2014.

[5] Ahsan, H., Zainab, I. And Ali, K.., Determinants of Food Price Inflation in Pakistan. The Lahore Journal of Economics, 17(1):101-128, 2012.

[6] Changchun, H. And Sean, R., Determinants of commodities Prices in Hong Kong. SAR. IMF Working Paper Asia and Pacific Department,. 2011.

[7] Abdullah, M. And Kalim, R., Determinants of food price inflation in Pakistan. Paper Presented in the Conference of University of Management and Sciences, 2009.
[8] Balkrishnan, P., Industrial Price Behavior in India: An Error-Correction Model. Journal of Development Economics, 37(2): 309-326. 1992.

[9] Balkrishnan, P., How Best to Model Inflation in India. Journal of Policy Modeling, 16(6): 677-683, 1994.

[10] Khan, A. H., And Qasim, M. A., Inflation in Pakistan revisited. Pakistan Development Review, 35(4): 747-759. 1996.

[11] Tan, B. H., And Cheng, Y. M., Inflation in Malaysia "International journal of Social Economics"29(5): 411-425, 2002.

[12] Kemal, M. A., Is Inflation in Pakistan a monetary phenomenon? The Pakistan Development Review,45(2): 213-220, 2006.

[13] Qayyum, A., Money, inflation, and growth in Pakistan. The Pakistan Development Review, Volume 45(2), pp. 203-212, Islamabad, 2006.

[14] Schimimelpfenning, A., And Khan, M.S.. Inflation in Pakistan. The Pakistan Development Review, 45(2): 185-202, 2006.

[15] World Bank, World Development Indicators. Washington Dc, World Bank CDROM, 2014.

[16] Abdullah, M. And Kalim, R., Determinants of food price inflation in Pakistan. Paper Presented at the 1st International Conference on Business Management, University of Management and Technology, Lahore, Pakistan, 2011.

[17] Khan, A. A., Bukhari, S. K. And Ahmad, Q. M., Determinants of Recent Inflation in Pakistan (Research Report No. 66). Karachi, Pakistan: Social Policy and Development Center, 2009.

[18] Akhtar, S., Macroeconomics of Food inflation in Pakistan. NUST Journal of Business and Economic, 2(1):10-23, 2009.

[19] Khan, R. E. A. And Gill A. R., Determinants of inflation: A case of Pakistan (1970-2007).Journal of Economics, $1(1): 45-51,2010$.

[20] Mushtaq, K., A.,Abedullah, G. And Ahmad, F., Impact of Monetary and Macroeconomic Factors on Wheat Prices in Pakistan: Implications for food Security. The Lahore Journal of Economics, 16(1): 95-110, 2011.

[21] Nguyen, H. M., Cavoli, T., And Wilson, J. K., The Determinants of Inflation in Vietnam, 2001-09. ASEAN Economic Bulletin, 29(1): 1-14, 2012.

[22] Faiza, Determinants of Inflation in Pakistan. Interdisciplinary Journal of Contemporary Research in Business, 4(9): 245-252, 2013.

[23] Abdullah, M., And Kalim, R., Determinants of food price inflation in Pakistan. Paper Presented in the Conference of University of Management and Sciences, 2009.

[24] Kemal, A. And Ali, M., The Determinants of Food Prices in Pakistan "The Lahore Journal of Economics" 17(1): 101-128, 2012.

[25] Khan, A. H. And Qasim, M. A., Inflation in Pakistan revisited. Pakistan Development Review, 35(4): 747-759, 1996.

[26] Khan, M., Inflation and Growth in MCD Countries. Mimeo, 
paper: International Monetary Fund. (2005): pp. 101-128. 2005.

[27] United Nations, High Food Prices in Pakistan: Impact Assessment and the Way Forward. UN Inter Agency Assessment Mission. Prepared for Ministry of Food, Agriculture and Livestock, Government of Pakistan, Islamabad. 2008.

[28] Ghaffar, Chaudhry, M.G.,Shamim, A.S. And Salam.A., Agricultural Input Subsidies in Pakistan Nature and Impact. The Pakistan Development Review,34(4): 711-722, 1995.

[29] Qadir, A.,Tayyaba.,Nadeem,Z. And Syed, A., Impact of Taxes on Inflation in Pakistan. Journal of Management and Social Sciences, 8(2): 31-41, 2012.

[30] Balqees, F., Elasticity and Buoyancy of the Tax system in Pakistan. The Pakistan Development Review, 43 (1): 73-93, 2004.

[31] Ayalew, B. Y., Explaining the Current Sources of Agricultural Inflation in Ethiopia: A Macro- Econometric
Approach. Addis Ababa: National Bank of Ethiopia. Processed. 30(3): 249-263, 2007.

[32] Abdullah, M. And Kalim, R., Determinants of food price inflation in Pakistan. Paper Presented in the Conference of University of Management and Sciences, 2009.

[33] Josef, L., Loening, D.,Durevall, Y. A. And Birru., Inflation Dynamics and Food Prices, Agricultural Economy: The Case of Ethiopia. Policy Research Working Paper No. 4969, 2009.

[34] Ahmed, M., Sulaiman, D., Muhammad N. And Ghulam, R., Determinants of Recent Inflation in Pakistan. Pakistan Journal of Commerce and Social Sciences,8(1): 170- 184, 2014.

[35] Anam, S., Allah R., And Zeeshan F., Determinants of Food Price Inflation in Pakistan. European Academic Research, Vol. I, , ISSN, 2286-4822 www.euacademic.org. 2014.

[36] Abdullah, M. And Kalim, R., Determinants of food price inflation in Pakistan. Paper Presented at the 1st International Conference on Business Management, University of Management and Technology, Lahore, Pakistan, 2011. 